\title{
Methotrexate pneumonitis: review of the literature and histopathological findings in nine patients
}

\author{
S. Imokawa, T.V. Colby, K.O. Leslie, R.A. Helmers
}

\begin{abstract}
Methotrexate pneumonitis: review of the literature and histopathological findings in nine patients. S. Imokawa, T.V. Colby, K.O. Leslie, R.A. Helmers. (C)ERS Journals Ltd 2000. ABSTRACT: Pneumonitis is a serious and unpredictable side-effect of treatment with methotrexate (MTX) that may become life-threatening. The clinical and histological features of nine cases of MTX pneumonitis are reported and the literature reviewed.

The typical clinical symptoms include progressive shortness of breath and cough, often associated with fever. Hypoxaemia and tachypnoea are always present and crackles are frequently audible. Chest radiography reveals a diffuse interstitial or mixed interstitial and alveolar infiltrate, with a predilection for the lower lung fields. Pulmonary function tests show a restrictive pattern with diminished diffusion capacity. Lung biopsy reveals cellular interstitial infiltrates, granulomas or a diffuse alveolar damage pattern accompanied by perivascular inflammation. These clinical and pathological findings are not specific to MTX pneumonitis and can be seen with other drug-induced lung toxicities.

It is important that all patients receiving methotrexate be educated concerning this potential adverse reaction and instructed to contact their physicians should significant new pulmonary symptoms develop while undergoing therapy. If methotrexate pneumonitis is suspected, methotrexate should be discontinued, supportive measures instituted and careful examination for different causes of respiratory distress conducted.
\end{abstract}

Eur Respir J 2000; 15: 373-381.

Dept of Laboratory Medicine and Pathology, Mayo Clinic Scottsdale, Scottsdale, Arizona, USA

Correspondence: T.V. Colby, Dept of Laboratory Medicine and Pathology, Mayo Clinic Scottsdale, 13400 East Shea Boulevard, Scottsdale, AZ 85259, USA. Fax: 6023018372

Keywords: Cellular interstitial pneumonia diffuse alveolar damage

granuloma

methotrexate pneumonitis

surgical lung biopsy

Received: April 281999

Accepted after revision September 301999
Methotrexate (MTX) is a folic acid antagonist that inhibits cellular reproduction by causing an acute intracellular deficiency of folate coenzymes [1]. Initially used as an antineoplastic drug, MTX has been shown to be an effective anti-inflammatory agent, and is now widely used for nonneoplastic inflammatory conditions including psoriasis [2], primary biliary cirrhosis [3], inflammatory bowel diseases [4] and, most commonly, rheumatoid arthritis (RA) [5].

Pneumonitis is a serious and unpredictable side-effect of treatment with MTX [6], the prevalence of which is reported to be $0.3-7.5 \%$ [7]. Since its first description in 1969 [8], >120 cases have been reported in the English language literature. The clinical features [6] and risk factors for MTX pneumonitis, especially in RA patients [9], have been reported recently. Lung biopsy has been performed in a minority of patients with MTX pneumonitis and has demonstrated interstitial inflammation and fibrosis, non-necrotizing granulomas, giant cells, tissue eosinophils, type II pneumocyte hyperplasia and increased intra-alveolar macrophages [10-13]. Many of the descriptions have been brief, with few details.

Here the clinical and histopathological features of lung biopsy specimens from patients with presumed MTX pneumonitis are presented and the literature on this problem reviewed.

\section{Materials and methods}

The consultation and teaching files of one of the authors (T.V. Colby) were searched for cases in which a diagnosis of MTX-induced lung toxicity had been suggested during the period January 1, 1987-June 30, 1998.

Cases were selected on the basis of the clinical history meeting the criteria outlined in table $1[9,14-16]$. Surgical lung biopsy was required for inclusion in this study. Clinical findings, chest radiographic features, therapy parameters and follow-up information were obtained from the referring physicians and the medical records.

Haematoxylin and eosin-stained sections were evaluated for the presence and extent of each of the following features on a scale of 0 (none) to 3 (widespread/severe): inter-stitial inflammation, interstitial fibrosis, honeycombing, bronchiolitis obliterans-organizing pneumonia pattern, intra-alveolar macrophage accumulation, foamy macrophage accumulation, hyaline membranes, type II pneumocyte hyperplasia, tissue eosinophils, perivascular inflammation, peribronchial inflammation, constrictive bronchiolitis, alveolar epithelial cell atypia, bronchial epithelial atypia and granulomas. The results of specific stains for organisms

Table 1. - Diagnostic criteria for methotrexate (MTX) pneumonitis

Exposure to MTX preceding the onset of pulmonary symptoms Exclusion of infection or alternative pulmonary disease Lung pathology consistent with drug-induced lung toxicity New or evolving infiltrates on chest radiographs

All of the above=probable MTX pneumonitis; the first three=possible MTX pneumonitis. [9, 14-16]. 
(Gomori's methenamine silver and/or acid-fast stains) were also recorded.

English language articles dating back to 1966 were

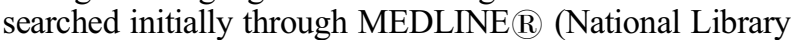
of Medicine, Bethesda, MD, USA) using the Medical Subject Headings keywords "methotrexate", "pneumonitis" and "lung toxicity". Manual searches of other English language literature databases were also performed. Only literature cases with detailed clinical summaries were included in this review. Pertinent clinical, radiographic, laboratory and histological data were abstracted.

\section{Literature review}

There have been approximately 123 cases of MTXinduced pneumonitis reported in the English language literature (table 2-6) $[8,10,14,15,17-71]$. These comprised $47(38.2 \%)$ males and $76(61.8 \%)$ females of mean age 49.3 yrs (range 3-79 yrs). The lung was examined histologically in 49 cases [8, 10, 14, 17-49]: surgical lung biopsy in 22 [8,10,14, 17-28], transbronchial lung biopsy in 14 [29-40] and percutaneous lung biopsy in one [41]. Post mortem histological examination was carried out in $15[25,26,29,30,42-48]$, four of whom had undergone previous lung biopsy $[25,26,29,30]$. The method of biopsy was not described in one case [49].

The background illnesses for which MTX had been given included RA, leukaemia (in remission), cancer, psoriasis, primary biliary cirrhosis, lymphoma, polymyositis, ectopic pregnancy, asthma, mycosis fungoides, pemphigus vulgaris, medulloblastoma, polyarticular juvenile RA, psoriatic arthritis and chronic obstructive pulmonary disease (table 2). The doses of MTX among the cases ranged 2.5-1,400 mg. week $^{-1}$ (table 2$)$. Forty-seven $(38.2 \%)$ patients were treated with MTX only. Concomitant drugs administered with MTX included antineoplastic agents [19, 24, 25, 30, $35,44,45,48,53,54]$, nonsteroidal anti-inflammatory drugs (NSAIDs) $[14,17,20,21,23,27,28,31,33,36$, $41,57,59,60,63,66,68,69]$ and others $[10,15,17,22$, $27,32,34,37,38,42,46,49,59-61,65,67,69]$. Thirty-

Table 2. - Background diseases of methotrexate (MTX) pneumonitis: literature review

\begin{tabular}{lrcc}
\hline & Total & $\begin{array}{c}\text { Histological } \\
\text { study } \\
(\mathrm{n}=49)\end{array}$ & $\begin{array}{c}\text { Dose of } \\
\text { MTX } \\
\mathrm{mg} \cdot \mathrm{week}^{-1}\end{array}$ \\
\hline RA & 62 & 24 & $2.5-15$ \\
Leukaemia (in remission) & 23 & 8 & $20-80$ \\
Cancer (breast, lung, other) & 10 & 9 & $15-1400$ \\
Psoriasis & 8 & 2 & $2.5-37.5$ \\
Primary biliary cirrhosis & 6 & 1 & 15 \\
Lymphoma & 3 & 2 & $6.25-80$ \\
Polymyositis & 2 & 1 & $20-50$ \\
Ectopic pregnancy & 2 & 0 & $12.5-88^{*}$ \\
Asthma & 1 & 1 & $5-15$ \\
Mycosis fungoides & 1 & 1 & 50 \\
Pemphigus vulgaris & 1 & 0 & $50-75$ \\
Medulloblastoma & 1 & 0 & 7.5 \\
Polyarticular juvenile RA & 1 & 0 & $0.5 * *$ \\
Psoriatic arthritis & 1 & 0 & 15 \\
COPD & 1 & 0 & $7.5-15$ \\
\hline
\end{tabular}

*: single intrathecal administration; **: $\mathrm{mg} \cdot \mathrm{kg}^{-1} \cdot \mathrm{week}^{-1}$. RA: rheumatoid arthritis; COPD: chronic obstructive pulmonary disease. (Data from $[8,10,14,15,17-71]$.) nine patients received systemic corticosteroids (prednisone 5-50 mg. day ${ }^{-1}$, or methylprednisolone $4 \mathrm{mg} \cdot$ day $^{-1}$; doses were not described in five) during MTX therapy [10, 14, $15,17,19,20,22-24,27,32,34,35,37,42,45,49,59,61$, $65,66,69]$.

MTX pneumonitis usually developed during MTX therapy, but a delayed type occurring 1-4 weeks after discontinuation of the drug was also reported [25, 36, 57]. Most patients with MTX pneumonitis showed subacute type with progression over several weeks $[7,11]$, but an acute type with rapid progression over several days $[15,20,32$, $51,59,70]$ and a chronic type presentation with a progression of several months [45] were also recognized. The most frequent presenting symptoms were dyspnoea, cough and fever (table 3). Tachypnoea and crackles were often present on physical examination (table 3 ). The peripheral blood eosinophil count was elevated $\left(>600\right.$ cells $\cdot \mathrm{mm}^{-3}$ or $6 \%$ of leukocytes) in 25 (20.3\%). Bronchoalveolar lavage (BAL) fluid cell analysis usually showed hypercellularity and lymphocytosis [37, 40, 49, 58, 65, 72-75], and mild eosinophilia [72] or neutrophilia [27, 38, 40, 49, 65, 75] were also reported. An increased percentage of either CD4 or CD8 lymphocytes were reported [37, 72-75].

Concomitant side-effects due to MTX were present in 32 cases $[10,14,15,22,29,30,37,39,40,42,43,45,48,50$, $55-57,60,61,63,67,68]$ : liver enzyme elevation or liver dysfunction (12 cases), oral ulcer (six cases), skin rash (six cases), stomatitis (three cases), haematological complications such as pancytopenia or leukopenia or acute megaloblastic anaemia (five cases), hypercalcaemia (one case); and convulsion (one case). The cumulative dose of these patients ranged $42-9,800 \mathrm{mg}$. Some patients had more than one extrapulmonary complication.

Pulmonary function studies were described in 27 cases. Fourteen of 19 patients in whom vital capacity was measured showed a restrictive ventilatory abnormality $[10,27$, $29,36-39,41,69,71]$ and two of seven in whom forced expiratory volume in one second was measured showed an obstructive ventilatory pattern $[10,36,39]$. All 18 patients examined for diffusing capacity exhibited a decreased single-breath diffusing capacity for carbon monoxide $[10,15,27,37-39,41,42,58,67,69]$. Arterial blood gas analysis was reported in 77 cases, and 76 of these showed hypoxaemia $(3.5-10.1 \mathrm{kPa}(26-76 \mathrm{mmHg}))[10$, $14,15,17,20,21,23-25,27-29,31-40,42,43,45-47$, $49,52,55,57-59,61-63,67-69,70]$.

Table 3. - Clinical features of methotrexate pneumonitis: literature review

\begin{tabular}{lcc}
\hline & Total & $\begin{array}{c}\text { Histological } \\
\text { study }\end{array}$ \\
\hline Subjects n & 123 & 49 \\
Age yrs & 49.3 & 52.1 \\
Sex M/F & $47 / 76$ & $24 / 25$ \\
Shortness of breath/Dyspnoea & $101(82.1)$ & $38(77.6)$ \\
Cough & $100(81.3)$ & $38(77.6)$ \\
Fever & $94(76.4)$ & $38(77.6)$ \\
Chest pain & $12(9.8)$ & $5(10.2)$ \\
Tachypnoea & $52(42.3)$ & $28(57.1)$ \\
Crackles & $64(52.0)$ & $32(65.3)$ \\
\hline
\end{tabular}

Data are presented as n (\%). M: male; F: female. (Data from [8, $10,14,15,17-71]$.) 
Chest radiographic findings ranged from normal to widespread diffuse infiltrates (table 4). Most cases demonstrated an interstitial or mixed interstitial and alveolar pattern. Six cases presented with an alveolar pattern only $[15,25,27,32,53,67]$. Most of the patients demonstrated diffuse and/or lower lobe-dominant infiltrates. Upper lobe predominance was present in only three [10, 59, 64]. Pleural effusion was present in three $[10,18,47]$ and hilar or mediastinal adenopathy in five $[10,24,50,52]$. Highresolution computed tomography may show heterogeneous or patchy areas of ground-glass appearance, septal lines and/or fibrosis [27, 38, 63, 73].

The histological findings are summarized in table $5[8$, $10,14,17-49]$. Interstitial inflammation and fibrosis were the most common findings. Giant cells, tissue eosinophils and type II pneumocyte hyperplasia were found in 13 $(26.5 \%)$, nine (18.4\%) and $19(38.8 \%)$ cases, respectively. Granuloma formation was reported in 17 (34.7\%), nonnecrotizing or noncaseating granulomas in seven of these, and, in the remaining 10, the character of the granulomas was not described. Hyaline membranes were reported in four $(8.2 \%)$.

Table 6 summarizes the treatment and follow-up data. Thirty-two cases were treated with discontinuation of MTX therapy alone $[8,10,14,17,19,29,40,43,46,48$, $52,55,57,60,66,70]$, and sixty-five with corticosteroids and discontinuation of MTX. Most patients were also treated with a combination of empirical antibiotics and/or oxygen support. Follow up data were described in 121 cases: 99 improved, some of whom resolved completely. There were $21(15.8 \%)$ deaths $[10,23,26,27,30,31,33$, $40,42-49,61], 16$ caused by respiratory disease $[23,26$, $27,31,33,42-49,61]$. Methotrexate was continued in eight cases $[8,22,53]$, and all improved without steroid therapy. Sixteen additional patients were treated with reintroduction of MTX $[8,10,14,15,17,18,22,29,42$, $45,54,60,69]$, resulting in recurrence of pneumonitis in $25 \%[14,17,29,45]$.

\section{Results of current study}

Fifteen cases of presumed MTX-induced lung toxicity were found; adequate clinical history and follow-up data

Table 4. - Radiographic findings of methotrexate pneumonitis: literature review

\begin{tabular}{lcc}
\hline & $\begin{array}{c}\text { Total } \\
(\mathrm{n}=123)\end{array}$ & $\begin{array}{c}\text { Histological } \\
\text { study }(\mathrm{n}=49)\end{array}$ \\
\hline Interstitial infiltrate & $46(37.4)$ & $16(32.7)$ \\
Alveolar infiltrate & $6(4.9)$ & $3(6.1)$ \\
Interstitial and alveolar infiltrate & $40(32.5)$ & $20(40.8)$ \\
Normal & $5(4.1)$ & $0(0)$ \\
Other & & \\
$\quad$ Interstitial and nodular & & \\
$\quad$ (small nodules, 3-5 mm) & $3(2.4)$ & $3(6.1)$ \\
$\quad$ Interstitial, alveolar and & & \\
$\quad$ nodular* & $1(0.8)$ & $0(0)$ \\
$\quad$ Nodular (small nodules, $\sim 1 \mathrm{~cm})$ & $3(2.4)$ & $1(2.0)$ \\
$\quad$ Alveolar and nodular* & $1(0.8)$ & $0(0)$ \\
Not fully described & $18(14.6)$ & $6(12.2)$ \\
\hline
\end{tabular}

Data are presented as $\mathrm{n}(\%)$. *: size of nodules not fully described. "Interstitial infiltrate" includes reticular shadows and ground-glass shadows; "alveolar infiltrate" includes consolidation. (Data from $[8,10,14,15,17-71]$.)
Table 5. - Histological findings of methotrexate pneumonitis: literature review

\begin{tabular}{lc}
\hline Interstitial inflammation & $35(71.4)$ \\
Interstitial fibrosis & $29(59.2)$ \\
Intra-alveolar organization & $5(10.2)$ \\
Hyaline membranes & $4(8.2)$ \\
Increased tissue eosinophils & $9(18.4)$ \\
Granuloma formation & $17(34.7)$ \\
Giant cells & $13(26.5)$ \\
Type II pneumocyte hyperplasia & $19(38.8)$ \\
Increased intra-alveolar macrophages & $13(26.5)$ \\
Bronchiolitis obliterans & $4(8.2)$ \\
Bronchial epithelial cell atypia & $1(2.0)$ \\
\hline
\end{tabular}

Data are presented as $n(\%)(n=49)$. (Data from $[8,10,14,17-49]$.)

were available for nine and these comprised the cases in the study. The clinical findings are summarized in table 7. Eight patients fulfilled the "criteria" outlined in table 1 for probable MTX pneumonitis and the remaining one (patient 2) for possible MTX pneumonitis. The background diseases included RA in five, psoriasis in two, polymyalgia rheumatica in one, and combined RA and giant cell arteritis in one. There were three males and six females of age range 57-76 yrs (mean 69.1 yrs). One patient was known to have pre-existing interstitial lung disease, presumed to be due to RA. Regarding concomit.ant drugs, two patients were treated with prednisone (30 $\mathrm{mg} \cdot \mathrm{day}^{-1}$ in one and unknown dose in the other), three with NSAIDs, and one other with both prednisone $(5 \mathrm{mg}$. day $^{-1}$ ) and NSAIDs. One patient exhibited dizziness ascribed to the extrapulmonary adverse effects of MTX. All patients showed acute-to-subacute shortness of breath and seven cough. Because of progressive or severe symptoms, surgical lung biopsy was performed. The duration of MTX treatment prior to biopsy ranged 3 months -4 yrs, and the dose ranged 2.5-20 mg. week $^{-1}$. The dose was unknown in one patient. The descriptions of the chest radiographs at presentation included diffuse or bilateral infiltrates in eight patients, and the distribution was lower lobe-dominant in five. One patient exhibited only hyperinflation.

Lung tissue culture results were available in six cases and all were negative. Specific culture results could not be obtained for the remaining cases, although, based on the follow-up, the cultures were presumed to be negative.

Table 6. - Summary of therapeutic and follow-up data of methotrexate (MTX) pneumonitis literature review

\begin{tabular}{lcc}
\hline & Total & $\begin{array}{c}\text { Histological } \\
\text { study (n=49) }\end{array}$ \\
\hline Therapy & & \\
Discontinuation of MTX & 32 & 11 \\
Discontinuation of MTX+steroid & 65 & 30 \\
Other therapies/not fully described & 26 & 8 \\
Continuation of MTX & 8 & 2 \\
Reintroduction of MTX & 16 & 6 \\
Recurrence & 4 & 4 \\
No recurrence & 12 & 2 \\
Follow-up (n=121) & & \\
Improving & 99 & 31 \\
Progressive disease & 1 & 0 \\
Death caused by respiratory disease & 16 & 14 \\
\hline
\end{tabular}

(Data from $[8,10,14,15,17-71]$.) 
Table 7. - Clinical features of methotrexate (MTX) pneumonitis: current study

\begin{tabular}{|c|c|c|c|c|c|c|c|c|c|c|c|}
\hline $\begin{array}{l}\mathrm{Pt} \\
\text { No. }\end{array}$ & $\begin{array}{l}\text { Age } \\
\text { yrs }\end{array}$ & Sex & $\begin{array}{c}\text { Background } \\
\text { disease }\end{array}$ & $\begin{array}{l}\text { MTX } \\
\text { dose }\end{array}$ & $\begin{array}{l}\text { Therapy } \\
\text { duration }\end{array}$ & $\begin{array}{l}\text { Duration of } \\
\text { respiratory } \\
\text { symptoms }\end{array}$ & Symptoms & $\begin{array}{l}\text { Phys } \\
\text { exam }\end{array}$ & $\begin{array}{l}\text { Chest XR } \\
\text { findings }\end{array}$ & $\begin{array}{l}\text { Path } \\
\text { findings }\end{array}$ & $\begin{array}{l}\text { Outcome/ } \\
\text { Follow-up } \\
\text { duration }\end{array}$ \\
\hline 1 & 71 & $\mathrm{~F}$ & RA & 7.5 & 3 months & $2-3$ weeks & $\begin{array}{l}\text { Dyspnoea, } \\
\text { chest pain }\end{array}$ & $\begin{array}{l}\mathrm{Cr} \\
\mathrm{TPN}\end{array}$ & $\begin{array}{l}\text { Interstitial+ } \\
\text { nodular, diffuse, } \\
\text { lower lobe- } \\
\text { dominant }\end{array}$ & $\mathrm{CII}+\mathrm{Gr}$ & $\begin{array}{l}\text { Alive, improved } \\
\text { completely } \\
1 \text { week }\end{array}$ \\
\hline 2 & 74 & $\mathrm{~F}$ & RA & 20 & 16 weeks & 1-2 months & $\begin{array}{l}\text { Dyspnoea, } \\
\text { cough, } \\
\text { sputum, } \\
\text { fever }\end{array}$ & $\begin{array}{l}\text { Cr; } \\
\text { TPN }\end{array}$ & Hyperinflation & $\mathrm{CII}+\mathrm{Gr}$ & $\begin{array}{l}\text { Alive, improving } \\
6 \text { weeks }\end{array}$ \\
\hline 3 & 71 & M & RA & NA & 5 months & 2 weeks & $\begin{array}{l}\text { Dyspnoea, } \\
\text { dry cough }\end{array}$ & $\begin{array}{l}\text { Cr; } \\
\text { TPN }\end{array}$ & $\begin{array}{l}\text { Interstitial } \\
\text { diffuse }\end{array}$ & $\mathrm{DAD}$ & $\begin{array}{l}\text { Dead } \\
9 \text { days }\end{array}$ \\
\hline 4 & 65 & $\mathrm{M}$ & RA & 7.5 & $4 \mathrm{yrs}$ & 1 month & $\begin{array}{l}\text { Dyspnoea; } \\
\text { fever }\end{array}$ & & $\begin{array}{c}\text { Interstitial, } \\
\text { bilateral }\end{array}$ & DAD & $\begin{array}{l}\text { Dead } \\
6 \text { days }\end{array}$ \\
\hline 5 & 76 & $\mathrm{M}$ & RA & 7.5 & 11 months & 1 month & $\begin{array}{l}\text { Dyspnoea, } \\
\text { dry cough }\end{array}$ & $\mathrm{Cr}$ & $\begin{array}{c}\text { Interstitial } \\
\text { bilateral }\end{array}$ & CII & $\begin{array}{l}\text { Alive, improving } \\
6 \text { weeks }\end{array}$ \\
\hline 6 & 57 & $\mathrm{~F}$ & Psoriasis & 2.5 & 6 months & 1-2 weeks & $\begin{array}{l}\text { Dyspnoea, } \\
\text { dry cough, } \\
\text { fever }\end{array}$ & $\mathrm{Cr}$ & $\begin{array}{l}\text { Interstitial } \\
\text { lower lobe- } \\
\text { dominant }\end{array}$ & $\mathrm{CII}+\mathrm{Gr}$ & $\begin{array}{l}\text { Alive, improving } \\
3 \text { weeks }\end{array}$ \\
\hline 7 & 64 & $\mathrm{~F}$ & Psoriasis & 15 & 3 months & 10 days & $\begin{array}{l}\text { Dyspnoea, } \\
\text { dry cough }\end{array}$ & & $\begin{array}{l}\text { Infiltrate, } \\
\text { bilateral, } \\
\text { lower lobe- } \\
\text { dominant }\end{array}$ & DAD & $\begin{array}{c}\text { Alive, improved } \\
\text { but chronic res- } \\
\text { piratory failure } \\
19 \text { months }\end{array}$ \\
\hline 8 & 70 & $\mathrm{~F}$ & $\begin{array}{l}\text { Polymyal- } \\
\text { gia } \\
\text { rheumatica }\end{array}$ & 15 & $\begin{array}{c}3.5 \\
\text { months }\end{array}$ & $\begin{array}{c}\text { Several } \\
\text { days }\end{array}$ & $\begin{array}{l}\text { Dyspnoea, } \\
\text { dry cough, } \\
\text { fever }\end{array}$ & $\mathrm{Cr}$ & $\begin{array}{c}\text { Interstitial+ } \\
\text { alveolar, } \\
\text { bilateral, lower } \\
\text { lobe-dominant }\end{array}$ & DAD & $\begin{array}{l}\text { Alive, improving } \\
3 \text { weeks }\end{array}$ \\
\hline 9 & 74 & $\mathrm{~F}$ & $\begin{array}{c}\text { RA/giant } \\
\text { cell arteritis }\end{array}$ & 15 & 36 months & $\begin{array}{l}\text { Several } \\
\text { weeks }\end{array}$ & $\begin{array}{l}\text { Dyspnoea, } \\
\text { dry cough, } \\
\text { chest pain }\end{array}$ & $\mathrm{Cr}$ & $\begin{array}{l}\text { Interstitial+ } \\
\text { alveolar lower } \\
\text { lobe-dominant }\end{array}$ & CII & $\begin{array}{l}\text { Alive, improving } \\
5 \text { months }\end{array}$ \\
\hline
\end{tabular}

Patient (Pt) 1: negative immunofluoresence stains for Legionella and Pneumocystic carinii; negative bacterial, acid-fast and fungal culture of lung tissue; pat 3: negative immunoperoxidase stains for herpes I and II cytomegalovirus; negative bacterial and fungal culture of lung tissue; pt 4: negative fungal, bacterial, acid-fast and Legionella culture of lung tissue; negative viral, Legionella, fungal and bacterial culture of bronchoalveolar lavage (BAL) fluid; negative BAL fluid smear for Pneumocystic carinii; negative serum titre for Histoplasma, Coccidioides and Blastomyces; negative serum antigen for Cryptococcus; negative bacterial and fungal culture of blood; Pt 5: negative fungal, bacterial Legionella, acid-fast and viral culture of lung tissue; negative lung tissue smear for Pneumocystis carinii; negative direct immunofluorescence for Legionella; pt 7: negative acid-fast, fungal and bacterial culture of lung tissue; pt 9: negative acid-fast, fungal and bacterial culture of lung tissue. M: male; F: female; Phys exam: physical examination; XR: radiography; RA: rheumatoid arthritis; Cr: crackles; TPN: tachypnoea; CII: cellular interstitial infiltrate; Gr: granuloma; DAD: diffuse alveolar damage; NA: not available.

After the presumptive diagnosis of MTX toxicity, MTX was discontinued in all cases and corticosteroid therapy was started in eight. One patient's illness resolved completely within 1 week. Five patients improved steadily during the follow-up period ( 3 weeks -5 months), and one continued to have respiratory insufficiency requiring periodical oxygen support at 19 months follow-up. Two patients died because of respiratory failure 6 and 9 days after admission, respectively. No cause of pulmonary disease other than MTX was identified in any of the nine cases.

\section{Pathological findings}

The histological findings are shown in figures $1-5$ and are summarized in table 8 . Two main patterns were identified: 1) acute and organizing diffuse alveolar damage (DAD) in four patients; and 2) cellular interstitial infiltrates with or without granuloma formation in five.

Hyaline membranes were identified in three of four cases with the DAD pattern. Interstitial widening by a combi- nation of oedema, fibroblast proliferation and inflammatory cells, characteristic of the organizing phase of DAD, were observed in two.

Granuloma formation was identified in three subacute group cases, two had non-necrotizing granulomas and one had both necrotizing and non-necrotizing granulomas. Lung cultures were negative for organisms in the case with necrotizing granulomas.

All cases exhibited hyperplastic type II pneumocytes and interstitial lymphocytic infiltration. Perivascular (predominantly perivenular) inflammation was present in seven of nine $(77.8 \%)$ cases. Honeycomb change was not identified histologically in any cases. Alveolar epithelial atypia (seven cases), increased intra-alveolar macrophage accumulation (eight cases), airspace foamy macrophage accumulation ( six cases) and tissue eosinophils (three cases) were also observed. Other pathology noted included mucostasis in one case and organizing thrombi in one case. Special stains for organisms were performed in all cases and were negative. 


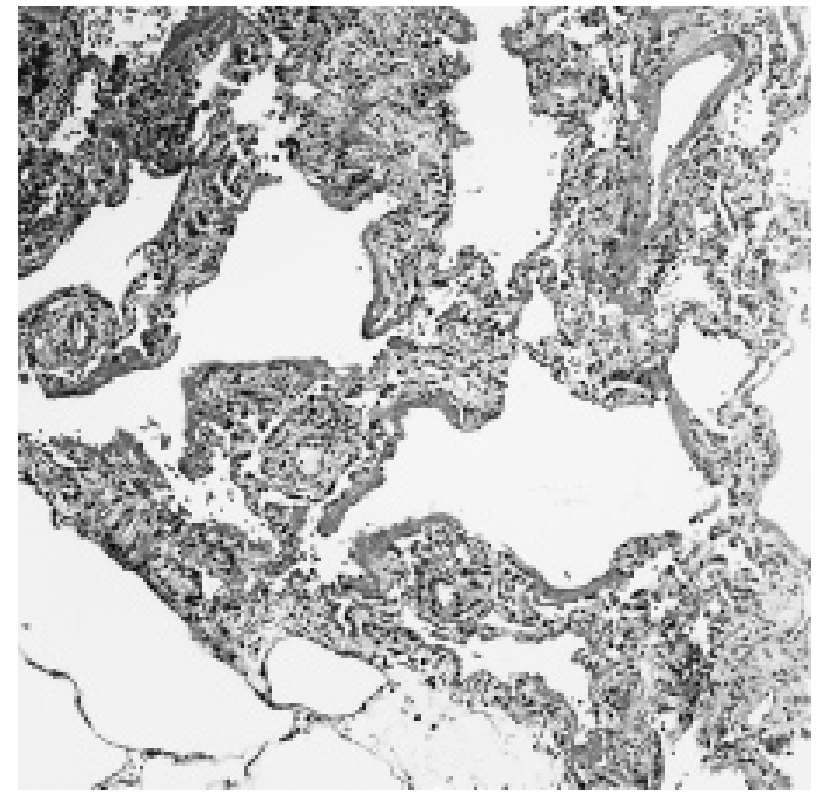

Fig. 1. - Photomicrograph showing diffuse alveolar damage with hyaline membranes in acute methotrexate pneumonitis (case 8 ).

\section{Discussion}

A definite diagnosis of drug-induced pneumonitis is difficult, because the clinical and histological findings are nonspecific [11]. In addition, the frequent use of multiple drugs in combination and other therapies, such as radiation or high-dose inspired oxygen, often confounds the chance of identifying the offending agent. The underlying disease may also complicate the identification of druginduced lung disease, as may opportunistic infections. Clinicopathological correlation is required for each individual case [76, 77]. In the final analysis, most drug reactions remain putative rather than proved, and the physician is usually confronted with making a diagnosis of "possible" or "probable" drug reaction.

Four sets of criteria for the diagnosis of MTX-induced lung toxicity have been reported [9, 14-16]. The most critical criteria for diagnosis appear to be an appropriate his-

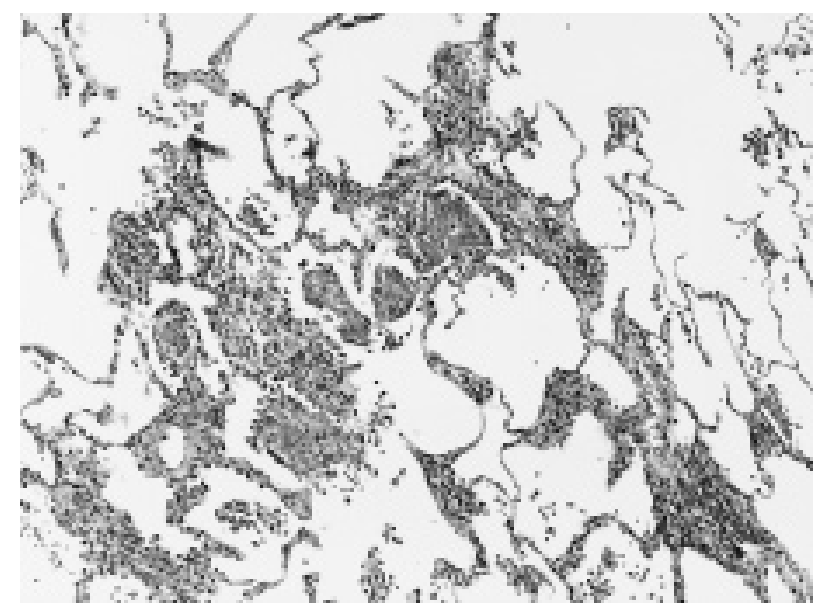

Fig. 2. - Patchy fibrinous exudate with mild chronic interstitial infiltrate in a subacute case of methotrexate pneumonitis (case 2).
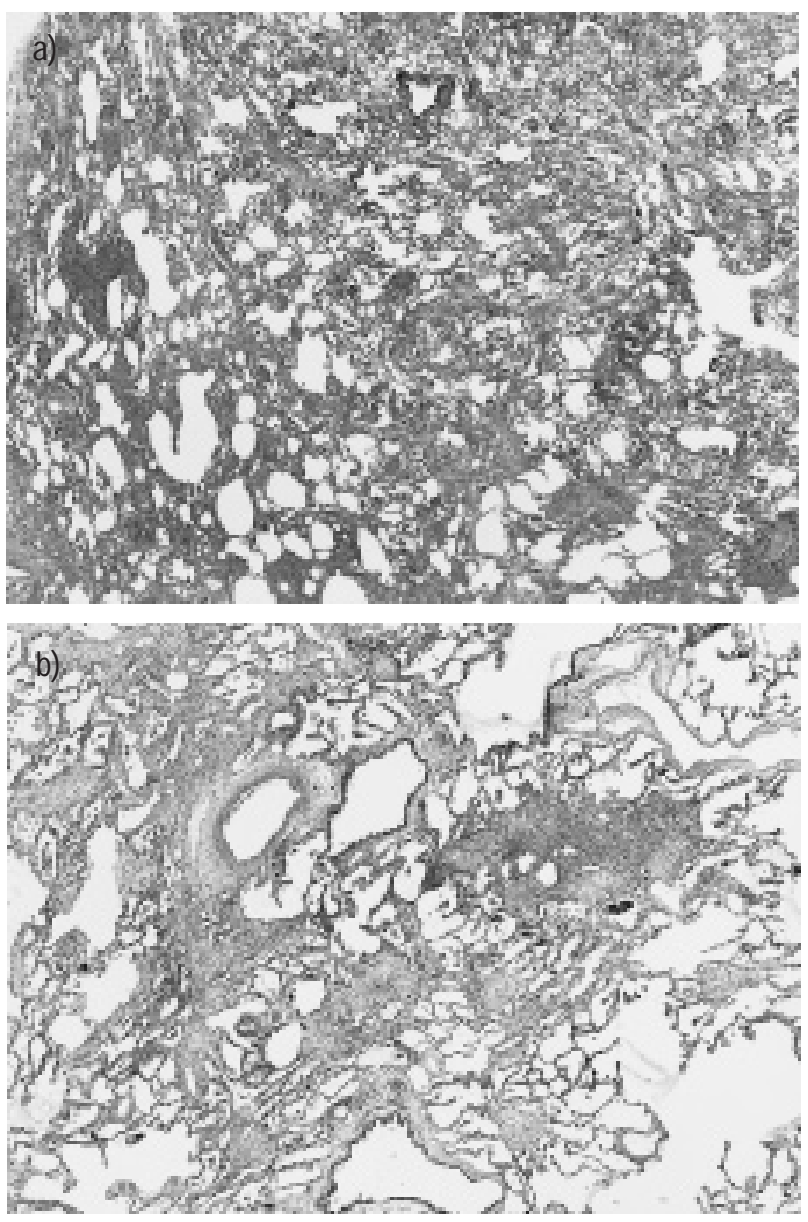

Fig. 3. - Low-power microscopic appearance of subacute methotrexate pneumonitis: a) diffuse moderate chronic interstitial infiltrates without fibrosis (case 6); and b) patchy parenchymal fibrosis and organization without honeycomb change, associated with a moderate chronic interstitial infiltrate (case 5).

tory of exposure, pulmonary infiltrates on chest radiography and exclusion of other pulmonary diseases, especially infections [13]. In cases in which a lung biopsy is performed, the histology should be consistent with what has been described in MTX-induced lung toxicity [9, 14-16]. The criteria used in the present study (table 1) depend heavily on the exclusion of other causes that might explain the findings. Serological study, pathological examination of lung biopsy specimens and microbiological work-up are necessary to adequately exclude infection. In clinical practice, MTX is frequently given with other drugs $[14,17$, 19-21, 23-25, 27, 28, 30, 31, 33, 35, 36, 41, 44, 45, 48, 53, $54,57,59,60,63,66,68,69]$ and a lack of published reports indicating that drugs other than MTX may cause a pulmonary reaction does not entirely exclude the possibility that they are the offending agents. For all of the above reasons, there remains the possibility that diseases other than MTX lung toxicity could fulfill the criteria in table $1:$ a clinical frustration that must be faced when considering drug-induced pneumonitis.

There were no appreciable differences between the present nine cases of MTX pneumonitis and those reported in the literature, including the subset of the 49 literature cases 
in which histological study was performed $[8,10,14,17-$ 49]. Patients generally present with acute-to-subacute symptomatology: shortness of breath or dyspnoea, cough and fever. Crackles were audible in more than half of the patients. Although, there were none in the present series, some reported cases showed a chronic clinical course or a delayed-type reaction after discontinuation of MTX [25,
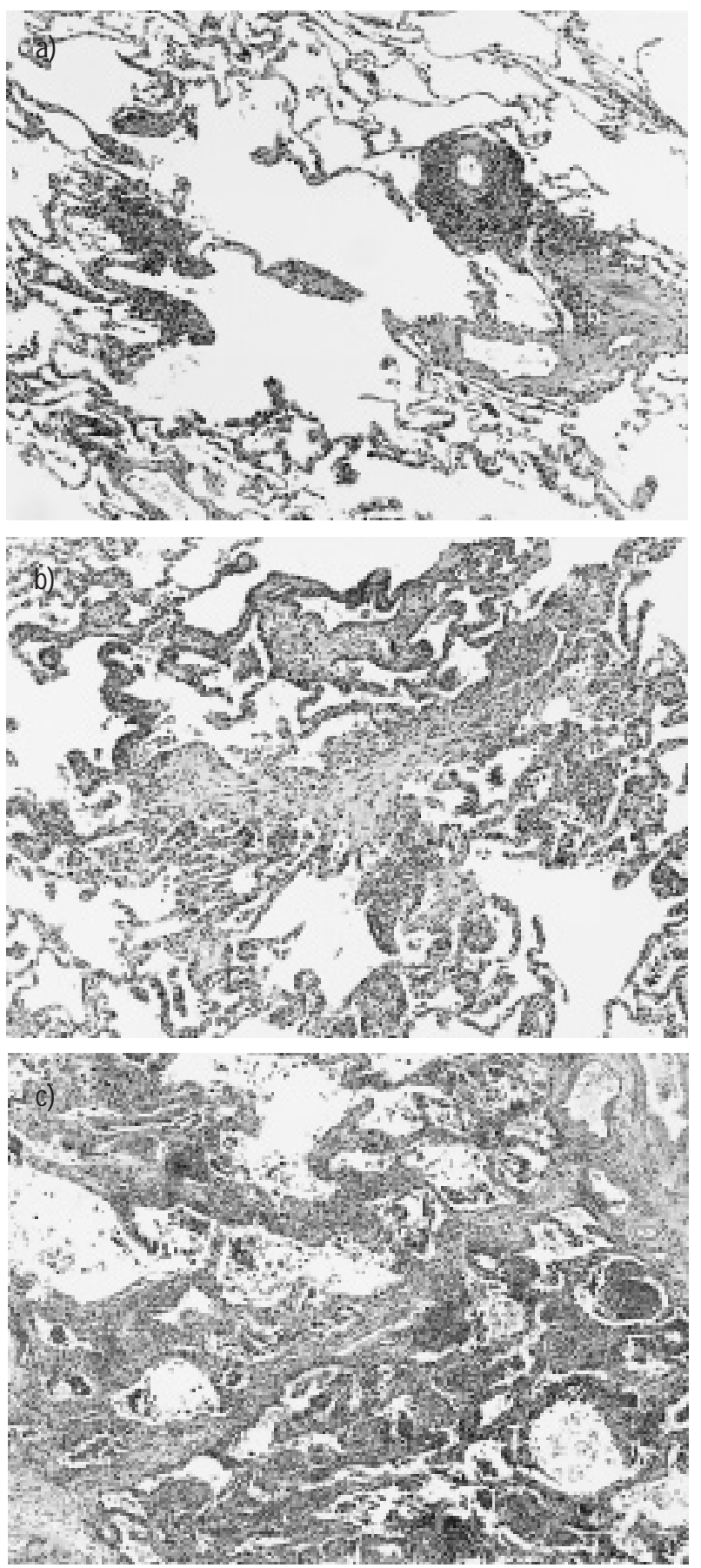

Fig. 4. - Photomicrograph showing subacute methotrexate pneumonitis: a) mild chronic interstitial infiltrate around an alveolar duct with prominent perivascular inflammation and no significant fibrosis (case 2); b) focus of airspace organization (centre) with surrounding interstitial infiltrate (case 7); and c) cellular interstitial infiltrate with increased alveolar macrophage numbers and mild-to-moderate alveolar septal thickening without honeycomb change (case 3 ).
36, 57]. Typical chest radiographic findings include interstitial and mixed interstitial and alveolar infiltrates with a predilection for the lower lung fields. Additional radiographic findings that have been reported in the literature reviewed include hilar or mediastinal lymphadenopathy, pleural effusion, alveolar pattern only and, rarely, normal findings.

The extrapulmonary complications reported for MTX include gastrointestinal intolerance, stomatitis, hepatotoxicity, haematological adverse effects and miscellaneous adverse effects such as alopecia, urticaria and small vessel vasculitis $[12,78]$. Adverse central nervous system reactions including headache, dizziness and memory impairment were also reported [79]. Overall, approximately a quarter of the patients with MTX pneumonitis [10, 14, 15, $22,29,30,37,39,40,42,43,45,48,50,52,55-57,60$, $61,63,67,68]$ (and one of the nine present cases) demonstrated extrapulmonary effects of the drug. Thus, it is helpful to look for extrapulmonary symptoms and signs when entertaining a diagnosis of MTX pneumonitis.

RA was the most frequent underlying disease in patients with MTX pneumonitis in the present series and in the literature (tables 2 and 7). This may simply reflect the population of patients receiving MTX, but it raises the question that RA itself, or other drugs used in its treatment,
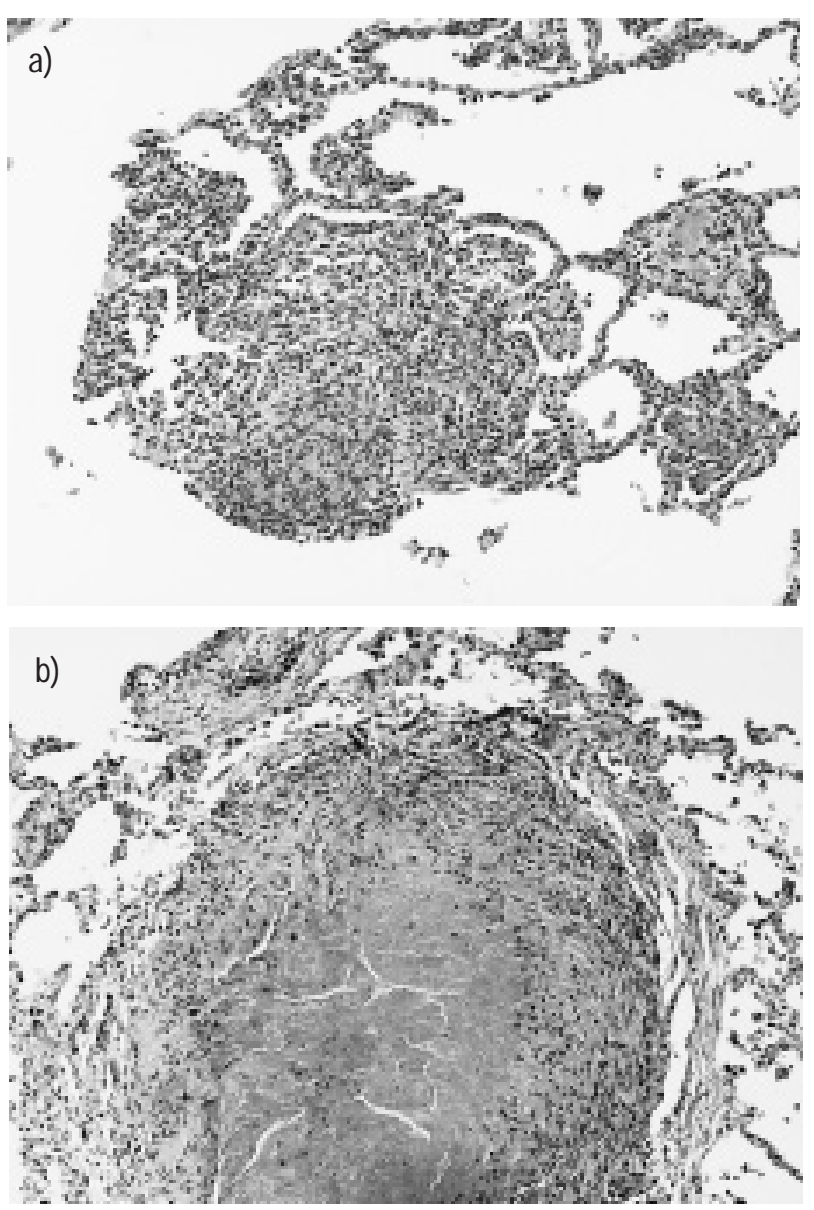

Fig. 5. - Photomicrograph showing granulomatous reaction in methotrexate pneumonitis (case 1). a) The granulomas in methotrexate are typically small and ill-defined. b) A single case in this series showed a necrotizing granuloma, indistinguishable from the necrotizing granulomas of infections. 
Table 8. - Summary of pathological findings in nine cases of methotrexate pneumonitis

\begin{tabular}{l} 
Acute cases \\
Diffuse alveolar damage with type II alveolar cell atypia \\
Subacute cases \\
Mild alveolar damage manifesting as interstitial \\
inflammatory infiltrate with lymphocytes and \\
type II cell hyperplasia \\
Small foci of organization, perivascular inflammation, \\
eosinophils and granuloma formation may be present. \\
(most granulomas are non-necrotizing, but rarely \\
small necrotizing granulomas may be present.) \\
Acute and organizing diffuse alveolar damage may be present \\
\hline
\end{tabular}

may play a role in this adverse reaction. Many RA patients with this disease had a history of treatment with other disease-modifying antirheumatic drugs (DMARDs) [14, $15,20,21,23,26,27,29,31,34,37,38,57-60,63,66$, $68,69]$. Some of these also showed adverse reactions to their DMARDs [14, 15, 20, 23, 26, 31, 57, 60, 66, 68], which might suggest that RA patients are prone to drug reactions in general. Unfortunately, the prevalence of MTX pneumonitis in RA relative to other diseases treated with MTX is unclear and the significance of "RA-susceptibility" remains to be clarified.

Although there were no cases of neoplastic disease in the present series, over a third of patients reported with MTX pneumonitis have had underlying neoplasms. The dose of MTX in the setting of neoplasms tended to be higher than that for non-neoplastic diseases (table 2). Some of these patients had also been treated with other cytotoxic agents in addition to MTX $[19,24,25,30,35,40,45,48,53$, 54], and it has been reported that the use of multiple chemotherapeutic agents in cancer patients may predispose to pulmonary drug toxicity [80].

The prognosis of patients with MTX pneumonitis has been considered relatively favourable $[7,11]$, but not entirely benign. According to the literature, $13 \%$ of patients died because of respiratory disease (table 6 ). In the present series, two $(22.2 \%)$ died because of respiratory disease and one developed chronic respiratory failure. All three of these patients showed an acute and organizing DAD pattern pathologically, probably underscoring the significant morbidity associated with the DAD pattern in general [81].

More than half of the patients with MTX pneumonitis carried a diagnosis of RA (table 2), a condition which commonly involves the lung [82]. The pathological findings observed by the authors in MTX pneumonitis, such as cellular interstitial infiltrates, DAD, tissue eosinophils and granuloma formation, are all reported in RA lung disease [82]. Thus, histology alone cannot differentiate between these two conditions. Clinical history and follow-up are critical.

Acute and organizing DAD and cellular interstitial infiltrates with or without granulomas were the main histological findings in the present patients with MTX pneumonitis. These patterns are nonspecific and can be seen in many conditions, including infections [83, 84]. One of the present cases showed necrotizing granulomas in addition to non-necrotizing granulomas. Cultures were negative for organisms in this case. Some patients receiving MTX therapy may be immunocompromised due to bone marrow suppression by the drug [78] and may be prone to infec- tions. Recently, it has been reported that opportunistic infection is a potential complication of low-dose MTX therapy even in the presence of a normal peripheral leukocyte count [85]. For these reasons, the careful exclusion of infection is an important clinical and pathological criterion. BAL may be a very useful tool for detecting an infectious process in some patients. When lung biopsy is performed, the tissue samples should be evaluated for infection with appropriate special stains and cultures.

The pathogenetic mechanisms of methotrexate pneumonitis remain unknown $[7,11]$. Some cases of methotrexate toxicity may be due to folate deficiency, whereas others are probably linked to immunoallergic or idiosyncratic reactions [1]. Findings suggesting a hypersensitivity reaction in the lung include: interstitial pneumonitis with small non-necrotizing granulomas on biopsy [10], increased tissue eosinophils $[10,14,18,23,26]$, lymphocytes and a reversed $\mathrm{CD} 4 / \mathrm{CD} 8$ ratio on $\mathrm{BAL}[72,73]$ and the clinical findings of fever, peripheral eosinophilia and response to corticosteroids [10-11]. Reports of spontaneous remission during methotrexate treatment $[8,22,53]$, and of rechallenge with the drug without recurrence of pneumonitis [8, $10,15,18,22,42,54,60,69]$, argue for an idiosyncratic reaction. A toxic drug reaction is suggested by the accumulation of methotrexate in lung tissue [86], the biopsy findings of alveolar or bronchial epithelial cell atypia [26, $45]$ and lung injury pattern [18, 20, 45, 47, 49], and resolution of lung disease after stopping or lowering the dose of the drug $[8,14,40,55,57,60]$. The fact that the pathological changes generally do not appear to be related to dose or duration of methotrexate therapy $[7,11,13]$ argues against this hypothesis. Further investigations are needed to elucidate the mechanisms of methotrexate pneumonitis.

\begin{abstract}
Acknowledgements. The authors thank the following physicians for providing clinical information or pathological materials pertaining to cases discussed in this series: S. Yousem, B.A. Little, P.T. Steinmetz, D.C. Olsen, R. DeFelice, J.C. Watts, M.M. Pevzner, C.L. Wisseman and R.S. Zeiders.
\end{abstract}

\section{References}

1. van Ede AE, Laan RFJM, Blom HJ, De Abreu RA, van de Putte LBA. Methotrexate in rheumatoid arthritis: an update with focus on mechanisms involved in toxicity. Semin Arthritis Rheum 1998; 27: 277-292.

2. Weinstein GD. Methotrexate. Ann Intern Med 1977; 86: 199-204.

3. Kaplan MM, Knox TA. Treatment of primary biliary cirrhosis with low-dose weekly methotrexate. Gastroenterology 1991; 101: 1332-1338.

4. Kozarek RA, Patterson DJ, Gelfand MD, Botoman VA, Ball TJ, Wilske KR. Methotrexate induces clinical and histologic remission in patients with refractory inflammatory bowel disease. Ann Intern Med 1989; 110: 353-356.

5. Weinblatt ME, Coblyn JS, Fox DA, et al. Efficacy of lowdose methotrexate in rheumatoid arthritis. $N$ Engl J Med 1985; 312: 818-822.

6. Kremer JM, Alarcon GS, Weinblatt ME, et al. Clinical, laboratory, radiographic, and histopathologic features of methotrexate-associated lung injury in patients with rheumatoid arthritis. A multicenter study with literature review. Arthritis Rheum 1997; 40: 1829-1837.

7. Barrera P, Laan RFJM, van Riel PLCM, Dekhuijzen PN, 
Boerbooms AMT, van de Putte LBA. Methotrexaterelated pulmonary complications in rheumatoid arthritis. Ann Rheum Dis 1994; 53: 434-439.

8. Clarysse AM, Cathey WJ, Cartwright GE, Wintrobe MM. Pulmonary disease complicating intermittent therapy with methotrexate. JAMA 1969; 209: 1861-1864.

9. Alarcon GS, Kremer JM, Macaluso M, et al. Risk factors for methotrexate-induced lung injury in patients with rheumatoid arthritis. A multicenter, case-control study. Methotrexate-Lung Study Group. Ann Intern Med 1997; 127: 356-364.

10. Sostman HD, Matthay RA, Putman CE, Smith GJW. Methotrexate pneumonitis. Medicine 1976; 55: 371-388.

11. Cooper JAD, White DA, Matthay RA. Drug-induced pulmonary disease. Part 1. Cytotoxic drugs. Am Rev Respir Dis 1986; 133: 321-340.

12. Goodman TA, Polisson RP. Methotrexate: adverse reactions and major toxicities. Rheum Dis Clin North Am 1994; 20: 513-528.

13. Cannon GW. Methotrexate pulmonary toxicity. Rheum Dis Clin North Am 1997; 23: 917-937.

14. Carson CW, Cannon GW, Egger MJ, Ward JR, Clegg DO. Pulmonary disease during the treatment of rheumatoid arthritis with low dose pulse methotrexate. Semin Arthritis Rheum 1987; 16: 186-195.

15. Searles G, McKendry RJR. Methotrexate pneumonitis in rheumatoid arthritis: potential risk factors. Four case reports and a review of the literature. J Rheumatol 1987; 14: 1164-1171.

16. Golden MR, Katz RS, Balk RA, Golden HE. The relationship of pre-existing lung disease to the development of methotrexate pneumonitis in patients with rheumatoid arthritis. J Rheumatol 1995; 22: 1043-1047.

17. Goldman GC, Moschella SL. Severe pneumonitis occurring during methotrexate therapy. Report of two cases. Arch Derm 1971; 103: 194-197.

18. Everts CS, Westcott JL, Bragg DG. Methotrexate therapy and pulmonary disease. Radiology 1973; 107: 539-543.

19. Lisbona A, Schwarts J, Lachance C, Frank H, Palayew MJ. Methotrexateinduced pulmonary disease. J Can Assoc Radiol 1973; 24: 215-220.

20. Cannon GW, Ward JR, Clegg DO, Samuelson CO. Acute lung disease associated with low-dose pulse methotrexate therapy in patients with rheumatoid arthritis. Arthritis Rheum 1983; 26: 1269-1274.

21. Engelbrecht JA, Calhoon SL, Scherrer JJ. Methotrexate pneumonitis after low-dose therapy for rheumatoid arthritis. Arthritis Rheum 1983; 26: 1275-1278.

22. Robbins KM, Gribetz I, Strauss L, Leonidas JC, Sanders M. Pneumonitis in acute lymphatic leukemia during methotrexate therapy. J Pediatrics 1973; 82: 84-88.

23. St Clair EW, Rice JR, Snyderman R. Pneumonitis complicating low-dose methotrexate therapy in rheumatoid arthritis. Arch Intern Med 1985; 145: 2035-2038.

24. Case records of the Massachusetts General Hospital. Weekly clinicopathological exercises. Case 37-1990. A 28-year-old man with increasing dyspnea, dry cough, and fever after chemotherapy for lymphoma. $N$ Engl J Med 1990; 323: 737-747.

25. Case records of the Massachusetts General Hospital. Weekly clinicopathological exercises. Case 6-1985. Progressive pneumonitis after chemotherapy for breast carcinoma. N Engl J Med 1985; 312: 359-369.

26. Elsasser S, Dalquen P, Soler M, Perruchoud AP. Methotrexate-induced pneumonitis: appearance four weeks after discontinuation of treatment. Am Rev Respir Dis 1989; 140: 1089-1092.
27. van der Veen MJ, Dekker JJ, Dinant HJ, van Soesbergen RM, Bijlsma JWJ. Fatal pulmonary fibrosis complicating low dose methotrexate therapy for rheumatoid arthritis. $J$ Rheumatol 1995; 22: 1766-1768.

28. Mulherin D, Cummiskey JM, Doyle GD, FirtzGerald O. Methotrexate pneumonitis in rheumatoid arthritis - a dramatic response to treatment. Br J Rheumatol 1992; 31 : 356-357.

29. Kerstens PJSM, van Loenhout JWA, van de Putte LBA. Methotrexate, pneumonitis, and infection. Ann Rheum Dis 1992; 51: 1179-1180.

30. Rohatgi PK, Halvarson L. Unilateral methotrexate-induced pneumonitis. J Nat Med Assoc 1980; 72: 896-899.

31. Gispen JG, Alarcon GS, Johnson JJ, Acton RT, Barger BO, Koopman WJ. Toxicity to methotrexate in rheumatoid arthritis. J Rheumatol 1987; 14: 74-79.

32. Ridley MG, Wolfe CS, Mathews JA. Life threatening acute pneumonitis during low dose methotrexate treatment for rheumatoid arthritis: a case report and review of the literature. Ann Rheum Dis 1988; 47: 784-788.

33. Newman ED, Harrington TM. Fatal methotrexate pneumonitis in rheumatoid arthritis. Arthritis Rheum 1988; 31 : $1585-1586$.

34. Green L, Schattner A, Berkenstadt H. Severe reversible interstitial pneumonitis induced by low dose methotrexate: report of a case and review of the literature. $J$ Rheumatol 1988; 15: 110-112.

35. Hand SH, Smith JK, Chaudhary BA. Methotrexate pneumonitis: a case report and summary of the literature. J Med Assoc Ga 1989; 78: 625-628.

36. Schwartz GF. Methotrexate induced pneumonitis in a young woman with psoriasis and rheumatoid arthritis. $J$ Rheumatol 1990; 17: 980.

37. Pourel J, Guillemin F, Fener P, Webanck L, Bene MC, Delorme N. Delayed methotrexate pneumonitis in rheumatoid arthritis. J Rheumatol 1991; 18: 303-304.

38. Leduc D, de Vuyst P, Lheureux P, Gevenois PA, Jacobovitz D, Yernault IC. Pneumonitis complicating low-dose methotrexate therapy for rheumatoid arthritis. Discrepancies between lung biopsy and bronchoalveolar lavage findings. Chest 1993; 104: 1620-1623.

39. Tsai JJ, Shin JF, Chen CH, Wang SR. Methotrexate pneumoitis in bronchial asthma. Int Arch Allergy Immunol 1993; 100: 287-290.

40. Sharma A, Provenzale D, McKusick A, Kaplan MM. Interstitial pneumonitis after low-dose methotrexate therapy in primary biliary cirrhosis. Gastroenterology 1994; 107: 266-270.

41. Clearkin R, Corris PA, Thomas SHL. Methotrexate pneumonitis in a patient with rheumatoid arthritis. Postgrad Med $J$ 1997; 73: 603-604.

42. Arnett FC, Whelton JC, Zizic TM, Stevens MB. Methotrexate therapy in polymyositis. Ann Rheum Dis 1973; 32: 536-546.

43. Rawbone RG, Shaw MT, Jackson JG, Bagshawe KD. Complication of methotrexate-maintained remission in lymphoblastic leukemia. BMJ 1971; 4: 467-468.

44. Lascari AD, Strano AJ, Johnson WW, Collins JGP. Methotrexate-induced sudden fatal pulmonary reaction. Cancer 1977; 40: 1393-1397.

45. Bedrossian CWM, Miller WC, Luna MA. Methotrexateinduced diffuse interstitial pulmonary fibrosis. South Med $J$ 1979; 72: 313-318.

46. Gutin PH, Green MR, Bleyer WA, Bauer VL, Wiernik $\mathrm{PH}$, Walker MD. Methotrexate pneumonitis induced by intrathecal methotrexate therapy. Cancer 1976; 38: 15291534. 
47. Bernstein ML, Sobel DB, Wimmer RS. Noncardiogenic pulmonary edema following injection of methotrexate into the cerebrospinal fluid. Cancer 1982; 50: 866-868.

48. Laosombat V, Mitarnun W, Mo-suwan L, Wacharasin R. Methotrexate-induced severe pneumonitis. J Med Assoc Thai 1982; 65: 611-617.

49. Hilliquin P, Renoux M, Perrot S, Puechal X, Menkes CJ. Occurrence of pulmonary complications during methotrexate therapy in rheumatoid arthritis. Br J Rheum 1996; 35: 441-445.

50. Verdich J, Christensen AL. Pulmonary disease complicating intermittent methotrexate therapy of psoriasis. Acta Derm Venereol Suppl (Stockh) 1979; 59: 471-473.

51. Robertson JH. Pneumonia and methotrexate. BMJ 1970; 2: 156 .

52. Filip DJ, Logue GL, Harle TS, Farrar WH. Pulmonary and hepatic complications of methotrexate therapy of psoriasis. JAMA 1971; 216: 881-882.

53. Pasquinucci G, Ferrara P, Castellari R. Daunorubicin treatment of methotrexate pneumonia. JAMA 1971; 216 : 2017.

54. Whitcomb ME, Schwarz MI, Tormey DC. Methotrexate pneumonitis: case report and review of the literature. Thorax 1972; 27: 636-639.

55. Phillips T, Jones DH, Baker H. Pulmonary complications following methotrexate therapy. Acad Dermatol 1987; 16: 373-375.

56. From E. Methotrexate pneumonitis in a psoriatic. $\mathrm{Br} J$ Dermatol 1975; 93: 107-110.

57. Louie S, Lillington GA. Low dose methotrexate pneumonitis in rheumatoid arthritis. Thorax 1986; 41: 703-704.

58. de Bandt M, Rat AC, Palazzo E, Kahn MF. Delayed methotrexate pneumonitis. J Rheumatol 1991; 18: 1943.

59. Hargreaves MR, Mowat AG, Benson MK. Acute pneumonitis associated with low dose methotrexate treatment for rheumatoid arthritis: report of five cases and review of published reports. Thorax 1992; 47: 628-633.

60. Cook NJ, Carroll GJ. Successful reintroduction of methotrexate-after pneumonitis in two patients with rheumatoid arthritis. Ann Rheum Dis 1992; 51: 272-274.

61. Trenkwalder P, Eisenlohr H, Prechtel K, Lydtin H. Three cases of malignant neoplasm, pneumonitis, and pancytopenia during treatment with low-dose methotrexate. Clin Investigator 1992; 70: 951-955.

62. Schoenfeld A, Reuben M, Vardy M, Ovadia J. Methotrexate pneumonitis in nonsurgical treatment of ectopic pregnancy. Obstet Gynecol 1992; 80: 520-521.

63. Bolla G, Disdier P, Harle JR, Verrot HD, Weiller PJ. Concurrent acute megaloblastic anemia and pneumonitis: a severe side-effect of low-dose methotrexate therapy during rheumatoid arthritis. Clin Rheumatol 1993; 12: 535-537.

64. Hassan W, Carpenter M, Kelly C. Acute pneumonitis associated with low dose methotrexate treatment for rheumatoid arthritis. Thorax 1993; 48: 191-192.

65. Cottin V, Tebib J, Massonnet B, Souquet PJ, Bernard JP. Pulmonary function in patients receiving long-term lowdose methotrexate. Chest 1996; 109: 933-938.

66. Alarcon GS, Koopman WJ. Nonperipheral accelerated nodules in a methotrexate-treated rheumatoid arthritis patient. Arthritis Rheum 1993; 36: 132-133.

67. Cook NJ, Lake FR. Hypercalcaemia with methotrexate pneumonitis, possible association with pulmonary granulomata. Aust N Z J Med 1996; 26: 715 .

68. Ohosone Y, Okano Y, Kameda H, et al. Clinical characteristics of patients with rheumatoid arthritis and methotrexate induced pneumonitis. $J$ Rheumatol 1997; 24: 2299-2303.

69. Salaffi F, Manganelli P, Carotti M, Subiaco S, Lamanna $\mathrm{G}$, Cervini C. Methotrexate-induced pneumonitis in patients with rheumatoid arthritis and psoriatic arthritis: report of five cases and review of the literature. Clin Rheumatol 1997; 16: 296-304.

70. Horrigan TJ, Fanning J, Marcotte MP. Methotrexate pneumonitis after systemic treatment for ectopic pregnancy. Am J Obstet Gynecol 1997; 176: 714-715.

71. Cron RQ, Sherry DD, Wallace CA. Methotrexate-induced hypersensitivity pneumonitis in a child with juvenile rheumatoid arthritis. J Pediatr 1998; 132: 901-902.

72. White DA, Rankin JA, Stover DE, Gellene RA, Gupta S. Methotrexate pneumonitis. Bronchoalveolar lavage findings suggest an immunologic disorder. Am Rev Respir Dis 1989; 139: 18-21.

73. Schnabel A, Richter C, Bauerfeind S, Gross WL. Bronchoalveolar lavage cell profile in methotrexate induced pneumonitis. Thorax 1997; 52: 377-379.

74. Akoun GM, Mayaud CM, Touboul JL, Denis M. Methotrexate-induced pneumonitis: diagnostic value of bronchoalveolar lavage cell data. Arch Intern Med 1986; 146: 804-805.

75. Akoun GM, Mayaud CM, Touboul JL, Denis M, Milleron BJ, Perrot JY. Use of bronchoalveolar lavage in the evaluation of methotrexate lung disease. Thorax 1987; 42: $652-655$.

76. Irey NS. Tissue reactions to drugs. Am J Pathol 1976; 82: 617-647.

77. Colby TV, Carrington CB. Interstitial lung disease. In: Thurlbeck WM, Churg AM, eds. Pathology of the Lung. 2nd Edn. New York, Thieme Medical Publishers, 1995; pp. 589-737.

78. Bannwarth B, Labat L, Moride Y, Schaeverbeke T. Methotrexate in rheumatoid arthritis. An update. Drugs 1994; 47: 25-50.

79. Wernick R, Smith DL. Central nervous system toxicity associated with weekly low-dose methotrexate treatment. Arthritis Rheum 1989; 32: 770-775.

80. Ginsberg SJ, Comis RL. The pulmonary toxicity of antineoplastic agents. Semin Oncol 1982; 9: 34-51.

81. Katzenstein ALA. Acute lung injury patterns: diffuse alveolar damage and bronchiolitis obliterans organizing pneumonia. In: Katzenstein ALA, Katzenstein and Askin's. Surgical Pathology of Non-neoplastic Lung Disease. 3rd Edn. Philadelphia, Saunders Company, 1997; pp. 14-47.

82. Yousem SA, Colby TV, Carrington CB. Lung biopsy in rheumatoid arthritis. Am Rev Respir Dis 1985; 131: 770777.

83. Katzenstein ALA. Infection I. In: Katzenstein ALA, Katzenstein and Askin's. Surgical Pathology of Nonneoplastic Lung Disease. 3rd Edn. Philadelphia, Saunders Company, 1997; pp. 247-285.

84. Katzenstein ALA. Infection II. In: Katzenstein ALA, Katzenstein and Askin's. Surgical Pathology of Nonneoplastic Lung Disease. 3rd Edn. Philadelphia, Saunders Company, 1997; pp. 286-310.

85. Lemense GP, Sahn SA. Opportunistic infection during treatment with low dose methotrexate. Am J Respir Crit Care Med 1994; 150: 258-260.

86. Anderson LL, Collins GJ, Ojima Y, Sullivan RD. A study of the distribution of methotrexate in human tissue and tumors. Cancer Res 1970; 30: 1344-1348. 